\title{
Carcass and Organ Characteristics of Broiler Chicken Fed Boiled Mango Kernel Composite Meal
}

\author{
Abang, F.B.P. ${ }^{1}$, Egahi. J.O. ${ }^{1} \&$ Gbakoron, D. ${ }^{1}$ \\ ${ }^{1}$ College of Animal Science, University of Agriculture Makurdi, Makurdi, Nigeria \\ Correspondence: Abang, F.B.P., College of Animal Science, University of Agriculture Makurdi, Makurdi, Nigeria. \\ E-mail: abang.favour2@gmail.com
}

Received: June 30, 2018; Accepted: July 22, 2018; Published: August 15, 2018

\begin{abstract}
A study on carcass and organ characteristics of broiler chicken fed boiled mango kernel composite meal (BMKCM) was carried out using complete randomized design (CRD). One hundred and eighty (180) broiler chickens were randomly allotted to four dietary treatments comprising of $0 \%$ (control), $10 \%, 15 \%$ and $20 \%$ inclusion levels of boiled mango kernel composite meal for T1, T2, T3 and T4 respectively. Each treatment was replicated thrice with fifteen (15) birds per replicate. The results of this study showed that there were no significant differences $(\mathrm{P}<0.05)$ across treatments with respect to meat yield and meat distributions among carcass cut-off parts. In terms of organ weights, significant differences $(\mathrm{P}<0.05)$ were observed in the heart, liver, kidney, spleen and gizzard weights, however, the result did not follow a regular pattern implying that, treatment would not have accounted for these differences. It is therefore concluded that, boiled mango kernel composite meal could be used up to $20 \%$ in the diets of broiler chickens without compromising the carcass and organ weights.
\end{abstract}

Keywords: boiled mango, maize, broiler finisher, carcass indices, organ indices

\section{Introduction}

Livestock feeds have become very expensive due to the high cost of conventional feedstuffs such as maize (Amao and Siyanbola, 2013; Daudu et al., 2015). The focus in the livestock industry (involving intensive production) is on alternative feedstuff; mostly those that can reduce production cost though compare favourably in quality to the conventional feedstuffs (not being deleterious to the animal's health). The most relevant option to arrest the present feed crisis of livestock industry is by-product utilization. The use of these alternative feed stuffs in livestock feed production will cut down feed prices, thus, making them more affordable by livestock farmers (Amao and Siyanbola, 2013). Mango kernel meets these requirements. Mango is an important fruit crop grown in the tropics mostly for its pulp. Mango belongs to the family Anacardiacea (Okpala, and Gibson-Umeh, 2013). According to Diarra (2014), mango seed (kernel) represents about 20-60\% of the fruits, it has limited food or industrial use in most producing countries and is therefore wasted. The kernel is a good source of carbohydrate (58-80\%), moderate protein (6-13\%) and fat (6-16\%) (Diarra and Usman, 2008). Mango has the ability to supplement methionine and lysine which are limiting in plant protein feeds stuffs (Saleh and Bello, 2015). Amao and Siyanbola (2013), reported that mango kernel is consumed in India by human beings in the form of porridges but in Nigeria, tonnes of mango seed kernel are generated from the fruits annually as waste and thereby constituting environmental nuisance (Kayode and Sani, 2008). Diarra et al. (2011) reported that $50 \%$ and $75 \%$ of maize can be replaced by mango seed kernel in broiler chicken starter and finisher diets respectively without adverse effect. The outstanding factors favouring the use of mango seed kernel meal as feed ingredients are its high energy contents, poor utilization by man and the facts that its production period (April-July) coincides with critical period for grain supply. Therefore, effort to substitute maize in poultry feed will significantly reduce the cost of production. The aim of this study is to determine the effect of various inclusion levels of boiled mango kernel composite meal on carcass and organs characteristics of broiler chicken as a replacement for maize.

\section{Materials and Methods}

The study was carried out in the poultry unit of Livestock Teaching and Research Farm, Federal University of Agriculture, Makurdi, Benue State, Nigeria. Makurdi is located in the middle belt region of Nigeria. Its geographic coordinates are latitude $7^{\circ} 44^{\prime}$ North, longitude $8^{\circ} 32^{\prime}$ East and has 104 meters elevation above the sea level. It has mean rainfall of $1259-2000 \mathrm{~mm}$ and mean annual temperature range of $23^{\circ} \mathrm{C}$ to $32^{\circ} \mathrm{C}$. The rainy period is between April to October and dry period from November to March (Anon, 2004). Mango seeds were collected during the 
month of May (peak of the mango season) in Gboko Local Government Area of Benue State, Nigeria. Mango kernel was removed by cracking manually with the aid of hammer. The water was allowed to boil $\left(100^{\circ} \mathrm{C}\right)$ before introducing mango kernel. Mango kernel was cooked for 20munites and rinsed thoroughly with cold water accompanied by sun-drying for 168 hours ( 7 days) so as to reduce the moisture content to less than $10 \%$ for prolonged storage. Soybean was well toasted to a dark brown colour to reduce the level of anti- nutrients such as tannin, oxalate, trypsin inhibitors, saponin, phytate, flavonoid, cyanides etc. The ingredients were crushed separately into fine grit (maize and soybean) and were later mixed at varying inclusion levels with other ingredients to formulate the various diets. The various diets were formulated to meet the nutritive requirements for broiler chicken. Boiled mango kernel composite meal was used to replace maize at $0 \%, 10 \%, 15 \%$ and $20 \%$ (Table 1).

Table 1. Composition of diet for broiler finisher using boiled mango kernel composite meal

\begin{tabular}{lllll}
\hline Ingredient & $\mathbf{0 \%}$ & $\mathbf{1 0 \%}$ & $\mathbf{1 5 \%}$ & $\mathbf{2 0 \%}$ \\
\hline Maize & 55.25 & 49.73 & 46.96 & 44.20 \\
BMKCM & 0.00 & 5.53 & 8.29 & 11.05 \\
Soybean & 31.00 & 31.50 & 32.00 & 32.00 \\
BDG & 6.00 & 5.00 & 5.00 & 5.00 \\
Blood meal & 3.00 & 3.50 & 3.00 & 3.00 \\
Bone meal & 3.00 & 3.00 & 3.00 & 3.00 \\
Salt & 0.50 & 0.50 & 0.50 & 0.50 \\
Lysine & 0.50 & 0.50 & 0.50 & 0.50 \\
Methionine & 0.50 & 0.50 & 0.50 & 0.50 \\
Premix & 0.25 & 0.25 & 0.25 & 0.25 \\
\hline Analyzed nutrients: & & & & \\
\hline ME (Kcal/kg) & 3102.72 & 2920.59 & 2945.00 & 2978.00 \\
CP (\%) & 20.63 & 20.53 & 20.51 & 20.40 \\
Lysine (\%) & 1.06 & 1.05 & 1.10 & 1.10 \\
Methionine (\%) & 0.31 & 0.20 & 0.30 & 0.30 \\
EE (\%) & 3.60 & 3.63 & 3.70 & 3.80 \\
CF (\%) & 4.08 & 3.81 & 3.88 & 3.86 \\
Ca ${ }^{2+}(\%)$ & 1.20 & 1.20 & 1.21 & 1.21 \\
P (\%) & 0.70 & 0.70 & 0.70 & 0.70 \\
\hline
\end{tabular}

One hundred and eighty (180) broiler chickens about same weights were randomly selected at eight (8) weeks old and assigned to four treatments $\left(T_{1}, T_{2}, T_{3}\right.$ and $\left.T_{4}\right)$ in a completely randomized design. Each treatment consisting of fourty five (45) birds and was replicated into three (3) with 15 birds each per replicate. The house was half walled, roofed with zinc coated metal sheets. The birds were managed intensively in cages of three tiers. Each tier was separated with wood. Wire mesh was used for the walls and doors to allow adequate ventilation/lighting. The dimension of each tier was $(1.0 \mathrm{~m} 2 \times 0.78 \mathrm{~m} 2)$. Litter materials (wood shavings) were used on the wooden floors. Each tier was equipped with adequate drinkers and feeding troughs. A floor space of about $0.007 \mathrm{~m}^{2}$ to $0.009 \mathrm{~m}^{2}$ per bird was provided. Source of lighting was provided with the use of electric bulbs to ensure adequate feed intake and local stove (Abacha) as source of heat. Conventional management practices were adopted. The initial body weights of the birds were taken and the birds were randomly distributed into the various experimental units. A known quantity of diets was served to the birds and the left over weighed. Feed and drinking water were given separate ad libitum throughout the period of experiment which lasted for eight (8) weeks. Mean daily feed consumption and weekly body weight gain were determined. At the end of eight (8) weeks, six (6) birds were randomly selected from each replicate and slaughtered. Birds were slaughtered by cutting their jugular veins with a sharp knife and allowed to bleed. After that the carcasses were weighed one after the other in the various treatments and scalded in warm water to soften the follicle of the feathers for easy removal followed by defeathering and then evisceration. The carcasses were finally cut into various parts and each part was weighed and kept separately according to treatments. Weight of cut-off parts and internal organs were determined using a sensitive digital scale. Processed boiled mango kernel composite meal was analyzed for proximate fractions according to the methods described by AOAC (1980). The data obtained on all the parameters studied were subjected to one-way analysis of variance (ANOVA) using Minitab statistical software version and least significant method (LSD) was used to separate means that differed significantly $(\mathrm{P}<0.05)$ according to Steel and Torrie $(1980)$. 


\section{Results and Discussion}

The mean values for cut off parts of broilers fed different inclusion levels of boiled mango kernel composite meal $(\mathrm{BMKCM})$ is presented in Table 2. The mean values for live weight ranged from 1783.3 to $1883.3 \mathrm{~g}$, slaughtered weight from 1613.3 to $1701.3 \mathrm{~g}$, de feathered weight from 1537.8 to $1629 \mathrm{~g}$, eviscerated weight from 1275.8 to $1350.5 \mathrm{~g}$, dressed weight from 1159.3 to $1221.2 \mathrm{~g}$, breast weight from $345.67-358.17 \mathrm{~g}$, drumstick from 185.83 to $197.83 \mathrm{~g}$, thigh weight from 178.83 to $182.50 \mathrm{~g}$, back weight from 169.50 to $190.50 \mathrm{~g}$, neck weight from 97.83 to $107.83 \mathrm{~g}$, head weight from 39.50 to $44.67 \mathrm{~g}$, shank weight from 72.00 to $83.33 \mathrm{~g}$ and wings weight from 137.17 to $143.17 \mathrm{~g}$. All the treatments showed no significant difference $(\mathrm{P}<0.05)$ on the carcass and cut off parts. This result agrees with the work of Diarra et al. (2010) and Ate- Biam (2016) who reported no significant differences $(\mathrm{P}<0.05)$ in the parameters measured when boiled mango kernel meal (BMKCM) and fermented mango kernel composite meal (FMKCM) was replaced with maize in broiler finisher diets. The results for the present study contradicts the findings of Abang et al. (2017) who observed significant $(\mathrm{P}<0.05)$ differences in the drum stick weights, head weights, breast weights, back weights and shank weights across treatment groups, with quails fed control diet having the highest mean weights and those placed on $50 \%$ least weights in all the aforementioned parameters when quails were fed sun-dried mango kernel meal. It appears the weights of these various cut- off parts reduced with increased supplementation of SMKM across treatments. Mango kernel is a rich source of tannin; tannins are known to interfere with protein digestibility and thereby rendering it unavailable, sun- drying process may not have efficiently reduced this anti- nutrient to a more tolerable level and this may have accounted for the better results recorded with birds fed BMKCM. Similar low weights of cut- off parts were also recorded across treatment by Amao and Sinyanbola (2013) and Rafiu et al. (2014) when broilers were fed heat treated mango kernel meal (HMKM) and sun- dried mango kernel meal (SMKM) respectively. The mean values for organ weights of broilers fed different inclusion levels of boiled mango kernel composite meal (BMKCM) is presented in Table 3. The mean values for heart ranged from 7.17- $9.67 \mathrm{~g}$, liver ranged from $32.67-41.50 \mathrm{~g}$, kidney from $10.00-14.00 \mathrm{~g}$, spleen from $1.00-2.17 \mathrm{~g}$, lungs from $10.67-12.00 \mathrm{~g}$, gizzard from $47.00-56.67 \mathrm{~g}$ and intestine from $121.50-134.17 \mathrm{~g}$. There were no significant differences $(\mathrm{P}<0.05)$ across the treatments for lungs and intestine weights, significant differences were recorded across the treatment groups for heart, liver, kidney, spleen and gizzard weights. This result partially agrees with the findings of Abang et al. (2017) who found no significant difference across the treatments for the Liver, gizzard and intestine weights while significant $(\mathrm{P}<0.05)$ differences were recorded on heart, lungs and kidney weights. Amao and Siyanbola (2013) reported significant $(\mathrm{p}<0.05)$ differences in internal organs of broilers fed SMKM on all the parameters measured with the control experiment having the highest weights. Again this may be due to the processing methods employed. Boiling is a better way of reducing antinutrients like tannins, phytates, etc. when compared with sun- drying. Birds placed on $0 \%$ inclusion were found to record the highest values for heart, liver, kidney, spleen, gizzard and intestine weights exception of lungs weights whose weight was highest in 15\% inclusion level. This result agrees with that of Abang et al. (2017) who recorded the highest weights in quails fed control diet. Similarly, Amao and Siyanbola (2013) also reported highest mean values in the control diet. Birds placed on 10\%inclusion level of BMKCM were found to record least values for heart, kidney, spleen and gizzard weights with exception of liver whose least weight was found with birds fed $20 \%$ BMKCM. There was no sign of abnormal increase (inflammation) of the organs measured in all the treatments. The differences observed in the treatments may be physiological as the results did not follow the regular pattern.

Table 2. Effect of Boiled Mango Kernel Composite Meal (BMKCM) on Carcass Cut-off Parts of Broilers

\begin{tabular}{llllll}
\hline Parameters & \multicolumn{2}{l}{ Treatments } & & \multirow{2}{*}{ P-values } \\
\cline { 2 - 5 } & $0 \%$ & $10 \%$ & $15 \%$ & $20 \%$ & \\
\hline Live Weight & $1883.3 \pm 318.90$ & $1783.3 \pm 116.90$ & $1808.3 \pm 241.70$ & $1816.7 \pm 231.70$ & 0.900 \\
Slaughtered Weight & $1701.3 \pm 330.40$ & $1613.3 \pm 107.90$ & $1665.2 \pm 235.60$ & $1656.0 \pm 224.50$ & 0.936 \\
De feathered Weight & $1629.5 \pm 311.00$ & $1537.8 \pm 101.60$ & $1588.0 \pm 214.80$ & $1586.5 \pm 215.50$ & 0.916 \\
Eviscerated Weight & $1350.5 \pm 226.50$ & $1275.8 \pm 124.30$ & $1305.3 \pm 185.10$ & $1332.8 \pm 203.90$ & 0.927 \\
Dressed Weight & $1221.2 \pm 267.10$ & $1159.3 \pm 123.90$ & $1192.7 \pm 177.60$ & $1204.3 \pm 185.40$ & 0.955 \\
Breast & $358.17 \pm 99.92$ & $345.67 \pm 42.94$ & $358.17 \pm 76.39$ & $356.83 \pm 61.23$ & 0.989 \\
Drumsticks & $195.00 \pm 34.08$ & $190.67 \pm 21.18$ & $185.83 \pm 22.76$ & $197.83 \pm 29.78$ & 0.882 \\
Thighs & $182.50 \pm 36.89$ & $178.83 \pm 23.35$ & $179.67 \pm 28.42$ & $181.83 \pm 34.29$ & 0.996 \\
Back & $190.50 \pm 51.47$ & $169.50 \pm 23.36$ & $184.67 \pm 29.36$ & $180.33 \pm 25.45$ & 0.753 \\
Neck & $107.83 \pm 19.56$ & $97.83 \pm 10.70$ & $106.00 \pm 16.49$ & $103.00 \pm 16.24$ & 0.724 \\
Head & $44.67 \pm 6.06$ & $39.50 \pm 2.07$ & $40.17 \pm 4.83$ & $44.67 \pm 5.57$ & 0.150 \\
Shanks & $82.50 \pm 15.83$ & $76.33 \pm 11.72$ & $72.00 \pm 9.94$ & $83.33 \pm 15.27$ & 0.431
\end{tabular}


Wings

$143.17 \pm 27.53$

$137.17 \pm 9.45$

$140.33 \pm 17.05$

$143.17 \pm 18.15 \quad 0.939$

Mean values are presented as mean \pm standard deviation. Means with different superscript in the same row shows that there is significant difference at $(P<0.05)$.

Table 3. Effect of boiled mango kernel composite meal (CBMKM) on internal organs of broilers

\begin{tabular}{llllll}
\hline Parameters & \multicolumn{2}{l}{ Treatments } & \multicolumn{3}{l}{ P- values } \\
\cline { 2 - 5 } & $0 \%$ & $10 \%$ & $15 \%$ & $20 \%$ & \\
\hline Heart & $9.67 \pm 2.58^{\mathrm{a}}$ & $7.17 \pm 0.98^{\mathrm{b}}$ & $9.00 \pm 1.41^{\mathrm{ab}}$ & $8.67 \pm 1.97^{\mathrm{ab}}$ & 0.148 \\
Liver & $41.50 \pm 5.54^{\mathrm{a}}$ & $33.83 \pm 3.55^{\mathrm{b}}$ & $37.17 \pm 5.53^{\mathrm{ab}}$ & $32.67 \pm 3.45^{\mathrm{b}}$ & 0.016 \\
Kidney & $14.00 \pm 2.83^{\mathrm{a}}$ & $10.00 \pm 1.27^{\mathrm{b}}$ & $13.17 \pm 2.79^{\mathrm{a}}$ & $11.67 \pm 1.21^{\mathrm{ab}}$ & 0.023 \\
Spleen & $2.17 \pm 0.98^{\mathrm{a}}$ & $1.00 \pm 0.00^{\mathrm{b}}$ & $1.50 \pm 0.55^{\mathrm{ab}}$ & $1.83 \pm 0.41^{\mathrm{a}}$ & 0.019 \\
Lungs & $11.67 \pm 2.88$ & $10.67 \pm 2.16$ & $12.00 \pm 3.46$ & $10.83 \pm 1.72$ & 0.785 \\
Gizzard (Intact) & $56.67 \pm 10.46^{\mathrm{a}}$ & $47.00 \pm 5.33^{\mathrm{b}}$ & $50.67 \pm 7.37^{\mathrm{ab}}$ & $50.83 \pm 4.45^{\mathrm{ab}}$ & 0.178 \\
Intestine & $134.17 \pm 22.17$ & $129.17 \pm 30.56$ & $127.33 \pm 21.32$ & $121.50 \pm 8.19$ & 0.799 \\
(Intact) & & & & & \\
\hline
\end{tabular}

Mean values are presented as mean \pm standard deviation. Means with different superscript in the same row shows that there is significant difference at $(P<0.05)$

\section{Conclusion}

Results revealed that boiled mango kernel composite meal could replace maize in broiler diet without affecting the carcass and organ weights of broiler chickens.

\section{Recommendation}

Boiled mango kernel composite meal can be recommended as a replacement for maize in broiler chicken feed up to $20 \%$ level of inclusion.

\section{REFERENCES}

Abang, F. B., Oko, O. K., \& Yelwa, J. T. (2017). Carcass and Organ Characteristics of Growing Japanese Quails (Coturnix coturnix japonica) Fed Sun-dried Mango (Mangifera spp) Kernel Meal as a Replacement for Maize. Annual Research and Review in Biology, 20(6), 1-7. https://doi.org/10.9734/ARRB/2017/33119

Amao, E. A., \& Siyanbola, M. F. (2013). Carcass and physiological response of broilers fed dry heat treated mango (Magnifera indica) kernel based diet. International Journal of Livestock Production, 4(3), 30-34. https://doi.org/10.5897/IJLP12.011

Anon, A. (2004). Council on Regulation of Environmental Information, 1-3.

AOAC. (1980). Official methods of analysis, 13th edition, Association of Official Analytical Chemists, Washington. DC.

Ate-Biam, M. (2017). Carcass and Organ Characteristics of Broiler Chicken Fed Diets Containing Fermented Mango Kernel Composite Meal as a Replacement for Maize. A Project Report to the Department of Animal Production, College of Animal Science, Federal University of Agriculture, Makurdi, Benue State, Nigeria.

Daudu, O. M., Igwoche, A., Idris, A., Olugbemi, T. S., \& Omage, J. J. (2015). Serum Metabolites and Meat Characteristics of BroilerChickens Fed Diets Containing Mango Seed Kernel. Journal of Animal Production, 27, 108-116.

Diarra, S. S., \& Usman, B. A. (2008). Growth performance and some blood parameters of broiler chickens fed raw or cooked mango kernel meal. International Journal of Poultry Science, 7(4), 315-318. https://doi.org/10.3923/ijps.2008.315.318

Diarra, S. S., Usman, B. A., \& Igwebuike, J. U. (2010). Replacement Value of Boiled Mango Kernel Meal for Maize in Broiler Finisher Diets. Arpn Journal of Agricultural And Biological Science, 5(1), 47-52.

Diarra, S. S, Saleh, B., Kwari, I. D., \& Igwebuike, J. U. (2011). Evaluation of boiled mango kernel meal as energy source by broiler chickens in the semi-arid zone of Nigeria. International Journal of Science and Nature, 2(2), 270-274.

Diarra, S. S., \& Usman, B. A. (2014). Mango seed kernel in poultry feeding. World poultry Science Journal, 7(2), 279-288. https://doi.org/10.1017/S0043933914000294 
Kayode, R. M. O., \& Sani, A. (2008). Physicochemical and proximate composition of mango kernel cake fermented with mono-culture of fungal isolates. Life Science Journal, 5(4), 55-63.

Minitab Statistical Software (2014). Minitab Inc P.A. USA. p.6.

Okpala, L. C., \& Gibson-Umeh, G. I. (2013). Physicochemical Properties of Mango Seed Flour. Official Journal of Nigerian Institute of Food Science and Techonology, 31(1), 23-27. https://doi.org/10.1016/S01897241(15)30052-7

Rafiu, T. A., Babatunde, G. M., \& Odunsi, A. A. (2014). Performance, Carcass and Meat Characteristics of Broiler BirdsFed Processed Mango Kernel Meal Based Diets. International Journal of Applied Research and Technology, 3(9), 23-30.

Saleh, N., \& Bello, K. M. (2015). Effects of Replacing Maize with Mango Seed Kernel Meal on Performance, Carcass Characteristics and Economic of Production of weaner rabbits. Scientific journal of Zoology, 4(3), 15-19.

Steel, R. G. D., \& Torrie, J. (1980). Principles and procedures of statistics. A biometrical approach 2nd Edn. McGraw Hills Books CO., New York.

\section{Copyrights}

Copyright for this article is retained by the author(s), with first publication rights granted to the journal.

This is an open-access article distributed under the terms and conditions of the Creative Commons Attribution license (http://creativecommons.org/licenses/by/4.0/). 